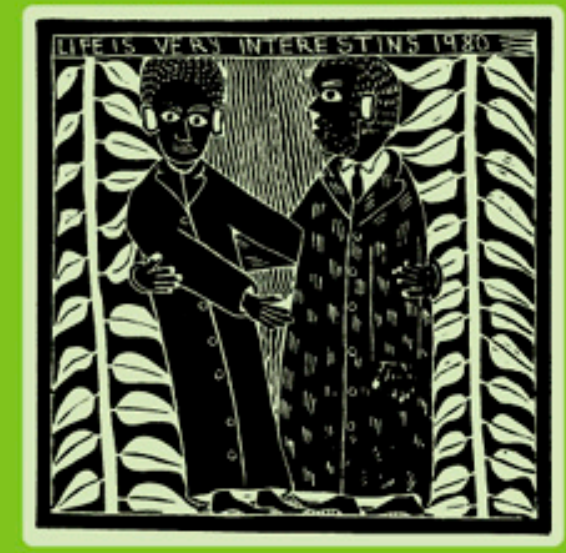

postcolonial contraventions cultural readings
of race, imperialism
and transnationalism

LAURA CHRISMAN 


\section{Postcolonial contraventions}

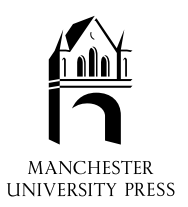


For my parents, Gale and Robert Chrisman 


\title{
Postcolonial contraventions
}

\author{
Cultural readings of race, \\ imperialism and transnationalism
}

LAURA CHRISMAN

\author{
Manchester University Press \\ Manchester and New York \\ distributed exclusively in the USA by Palgrave
}




\section{Copyright (C) Laura Chrisman 2003}

The right of Laura Chrisman to be identified as the author of this work has been asserted by her in accordance with the Copyright, Designs and Patents Act 1988.

Published by Manchester University Press

Oxford Road, Manchester M13 9NR, UK

and Room 400, 175 Fifth Avenue, New York, NY 10010, USA

www.manchesteruniversitypress.co.uk

Distributed exclusively in the USA by

Palgrave, 175 Fifth Avenue, New York,

NY 10010, USA

Distributed exclusively in Canada by

UBC Press, University of British Columbia, 2029 West Mall,

Vancouver, BC, Canada V6T 1Z2

British Library Cataloguing-in-Publication Data

A catalogue record for this book is available from the British Library

Library of Congress Cataloging-in-Publication Data applied for

\section{ISBN 0719058279 hardback \\ 0719058287 paperback}

First published 2003

$\begin{array}{lllllllllllllllllll}11 & 10 & 09 & 08 & 07 & 06 & 05 & 04 & 03 & & 10 & 9 & 8 & 7 & 6 & 5 & 4 & 3 & 2\end{array}$

Typeset by

D R Bungay Associates, Burghfield, Berks

Printed in Great Britain

by Bell \& Bain Ltd, Glasgow 